\title{
Meningkatkan Pengembangan Diri Dan Motivasi Anak Jalanan Di Yayasan Anak Bangsa Mandiri Banua
}

\author{
Emilda Prasiska ${ }^{1}$, RR. Ariessanty Alicia K.W ${ }^{2}$, Antoni Pardede ${ }^{3}$, Akhmad Rizkhi \\ Ridhani $^{4}$, Jarkawi $^{5}$
}

${ }^{l}$ Program Studi Pendidikan Kimia, Universitas Islam Kalimantan Muhammad Arsyad Al-Banjari, Banjarmasin, Indonesia

DOI: https://doi.org/10.29303/jpmpi.v4i2.767

Sitasi: Pariska, E., Alicia, K. W. R. R., Pardede, A., Ridhani, A. R., \& Jarkawi. (2021). Meningkatkan Pengembangan Diri Dan Motivasi Anak Jalanan Di Yayasan Anak Bangsa Mandiri Banua. Jurnal Pengabdian Magister Pendidikan IPA, $4(2)$

\section{Article history}

Received: 03 Maret 2021

Revised: 03 April 2021

Accepted: 27 Mei 2021

*Corresponding Author:

Emilda Prasiska, Program Studi Pendidikan Kimia, Universitas Islam Kalimantan Muhammad Arsyad Al-Banjari,

Banjarmasin, Indonesia; Email: emildaprasiska@gmail.com

\begin{abstract}
Anak jalanan merupakan anak yang beresiko, anak-anak yang tidak dapat berkembang secara optimal karena mereka hidup di jalanan. Anak jalanan memerlukan kegiatan-kegiatan yang positif selain bimbingan belajar. Pengembangan diri berhubungan dengan potensi-potensi diri yang dioptimalkan secara efektif dan kontinu. Potensi adalah modal manusia untuk tumbuh dan berkembang secara luar biasa jika dapat dideteksi, dimotivasi dan dikembangkan atau diaktualisasikan dalam kehidupan nyata. Metode yang digunakan dalam pengabdian ini adalah metode pelaksanaan penelitian tindakan yang terdiri dari persiapan, pelaksanaan (tindakan), observasi, evaluasi serta refleksi. Kegiatan yang dilakukan memperoleh 2 data yakni hasil lembar kegiatan dream activity dan lembar angket motivasi. Hasil data pada lembar kegiatan dream activity menunjukkan pengembangan diri anak pada setiap pertemuan mengalami peningkatan dengan rata-rata $85 \%$ berkategori baik. Hasil data pada lembar angket motivasi menunjukkan bahwa kegiatan pengabdian dapat meningkatkan motivasi belajar anak dengan diperoleh ratarata nilai pretest sebesar 77.9 dan nilai posttest sebesar 89.6. Dengan demikian kegiatan pengabdian yang dilakukan dapat menambah wawasan pengetahuan dan pengalaman anak jalanan tentang pengembangan diri sehingga meningkatkan pengembangan diri dan motivasi belajar anak jalanan.
\end{abstract}

Keywords: Motivasi; pengembangan diri; anak jalanan

\section{Pendahuluan}

Salah satu permasalahan sosial yang cukup kompleks di kota-kota besar adalah anak jalanan. Banyaknya anak-anak yang berkeliaran di jalan mulai dari perempatan lampu merah, terminal, pasar, pertokoan, bahkan mall, menjadi tempat-tempat anak jalanan melakukan aktivitasnya. Menurut UNICEF dalam Sugianto (2013) anak jalanan terbagi menjadi dua kelompok, yaitu children on the street dan children of the street. Children on the street adalah anak-anak yang bekerja di jalan dan masih tinggal dengan orang tua, saudara dan teman. Sedangkan Children of the street adalah deskripsi bagi anak-anak yang bekerja dan bermukim di sembarang tempat, seperti emper toko, taman kota, statiun KA, pasar dsb, dan mereka tidak mempunyai kontak dengan orang tua dan keluarga.

Anak jalanan adalah anak yang berusia kurang dari 16 tahun yang berada dijalanan untuk hidup maupun bekerja dengan melakukan kegiatan ekonomi dijalan, seperti pedagang asongan, sol sepatu, penjual koran, mengamen, mengelap kaca mobil, menyewakan payung saat hujan dan lain sebagainya (Marni, 2020). Anak jalanan termasuk bagian dari anak yang di lindungi oleh undangundang dimana menurut Undang-Undang Republik 
Indonesia Nomor 23 Tahun 2002 bahwa anak jalanan juga memiliki hak perlindungan anak yaitu hak agar dapat hidup, tumbuh, berkembang, dan berpartisipasi, secara optimal sesuai dengan harkat dan martabat kemanusiaan, serta mendapat perlindungan dari kekerasan dan diskriminasi.

Yayasan Anak Bangsa Mandiri Banua merupakan salah satu rumah singgah yang memperhatikan anak jalanan. Yayasan ini terletak di Jalan Cempaka IV, dimana yayasan ini didirikan berawal dari keprihatinan seorang ibu Irma terhadap keadaan anak-anak di lingkungan sekitar beliau. Dengan fasilitas seadanya anak-anak ini diajarkan bimbingan belajar berbagai mata pelajaran sekolah. Ada puluhan anak putus sekolah yang menjadi bagian dari rumah singgah Yayasan Anak Bangsa Mandiri Banua dan dibantu untuk melanjutkan pendidikan reguler maupun paket. Banyak dari mereka bekerja diusia yang masih sangat muda dan menjadi tulang punggung keluarga. Dalam mencari nafkah, ada beberapa anak yang rela melakukan kegiatan mencari nafkah di jalanan dengan kesadaran sendiri, namun banyak pula anak-anak yang dipaksa untuk bekerja di jalan (mengemis, mengamen, menjadi penyemir sepatu, dan lain-lain) oleh orang-orang di sekitar mereka, entah itu orang tua atau pihak keluarga lain, dengan alasan ekonomi keluarga yang rendah.

Menurut Haryadi (2020) Anak jalanan merupakan anak yang beresiko, anak-anak yang tidak dapat berkembang secara optimal karena mereka hidup di jalanan. Dimana anak jalanan lebih tertarik untuk melakukan pekerjaan seperti mengamen, atau meminta-minta di jalan dibandingkan pergi belajar. Ada beberapa hal yang melatar belakangi penyebab turunnya anak-anak ke jalanan, antara lain : sulitnya memenuhi segala kebutuhan hidup, keadaan keluarga yang tidak kondusif, dan korban urbanisasi yang pada akhirnya menyeret mereka pada situasi yang sulit (Sakman, 2016). Berdasarkan hasil wawancara yang dilakukan dengan ibu Irma, yang merupakan pengelola Yayasan Anak Bangsa Mandiri Banua, anak jalanan memerlukan kegiatan-kegiatan yang positif selain bimbingan belajar. Dimana kegiatan ini diharapkan dapat membantu mereka dalam mengoptimalkan pengembangan diri dan memotivasi mereka untuk dapat terus belajar.

Menurut Herawan (2016) Pengembangan diri berhubungan dengan potensi-potensi diri yang dioptimalkan secara efektif dan kontinu. Potensi adalah modal manusia untuk tumbuh dan berkembang secara luar biasa jika dapat dideteksi, dimotivasi dan dikembangkan atau diaktualisasikan dalam kehidupan nyata. Setiap anak itu memiliki potensi di dalam dirinya. Hanya saja terkadang potensi-potensi tersebut tidak muncul karena belum adanya upaya yang dilakukan untuk mengoptimalkan potensi tersebut. Anak jalanan juga memiliki hak untuk mengembangkan potensi yang ada pada dirinya, hanya saja ada faktor-faktor yang mempengaruhi potensi tersebut belum optimal. Oleh karena itu, perlu adanya upaya yg dilakukan untuk mengoptimalkan pengembangan diri anak jalanan.

Menurut Handayani (2020) pada dasarnya motivasi adalah suatu usaha secara sadar yang dilakukan oleh setiap individu untuk mengerahkan segala usaha dalam melakukan sesuatu. Jadi dalam memotivasi anak untuk terus melakukan kegiatan belajar, perlu adanya upaya-upaya yang mendukung mereka baik secara internal maupun eksternal.

Pengembangan diri dan motivasi memiliki kaitan antara satu dengan yang lainnya. Menurut Efendi (2018) Motivasi dan pengembangan diri memilki pengaruh positif terhadap kinerja seseorang. Oleh karena itu perlu adanya upaya yang dilakukan untuk meningkatkan pengembangan diri dan motivasi anak sehingga mereka dapat tumbuh dan berkembang secara optimal. Salah satu upaya yang dapat dilakukan untuk meningkatkan pengembangan diri dan motivasi anak jalanan adalah dengan melakukan kegiatan-kegiatan yang menyenangkan. Dimana dengan adanya kegiatankegiatan yang menyenangkan ini dapat memiliki pengaruh yang positif dalam meningkatkan pengembangan diri dan motivasi anak.

Berdasarkan hal tersebut, agar membantu mengatasi permasalahan mitra tim pengusul sepakat untuk membuat program Meningkatkan Pengembangan Diri dan Motivasi Anak Jalanan di Yayasan Anak Bangsa Mandiri Banua.

\section{Metode Pelaksanaan}

Pelaksanaan kegiatan pengabdian ini mengikuti aktivitas pelaksanaan penelitian tindakan yang terdiri dari Persiapan, Pelaksanaan (tindakan), observasi, evaluasi serta refleksi. Adapun untuk kegiatan pelaksanaanya antara lain:

\section{Persiapan}

Melakukan koordinasi dengan LPM Universitas Islam Kalimantan Muhammad Arsyad 
Al-Banjari. Penyusunan program pengabdian berdasarkan hasil analisis situasi, analisis khalayak sasaran, analisis materi dan analisis media.

2. Pelaksanaan Tindakan :

Meningkatkan pengembangan diri dan motivasi anak jalanan di Yayasan Anak Bangsa Mandiri Banua. Adapun rincian tindakan yang dilakukan dalam program pendampingan tersebut dapat dilihat pada tabel kegiatan.

Tabel 1. Kegiatan yang akan dilaksanakan.

\begin{tabular}{|c|c|c|}
\hline Kegiatan & Deskripsi & Waktu \\
\hline Character Building & $\begin{array}{l}\text { Kegiatan ini dilaksanakan } \\
\text { untuk memberikan } \\
\text { pengetahuan dan wawasan } \\
\text { kepada anak jalanan } \\
\text { tentang analisa strength } \\
\text { (kekuatan) dan potensi } \\
\text { dalam diri. }\end{array}$ & $\begin{array}{l}2 \times 60 \\
\text { menit }\end{array}$ \\
\hline $\begin{array}{l}\text { Self regulated } \\
\text { learning }\end{array}$ & $\begin{array}{l}\text { Kegiatan ini dilaksanakan } \\
\text { untuk memfasilitasi anak } \\
\text { dalam manajemen waktu. }\end{array}$ & $\begin{array}{l}2 \times 60 \\
\text { menit }\end{array}$ \\
\hline $\begin{array}{l}\text { Perencanaan } \\
\text { pengembangan diri } \\
\text { (Self Planing) }\end{array}$ & $\begin{array}{l}\text { Kegiatan ini dilaksanakan } \\
\text { untuk memfasilitasi anak } \\
\text { jalanan tentang self } \\
\text { planning dengan membuat } \\
\text { pohon mimpi (dream tree) }\end{array}$ & $\begin{array}{l}2 \times 60 \\
\text { menit }\end{array}$ \\
\hline $\begin{array}{l}\text { Membentuk } \\
\text { Kelompok dan } \\
\text { Pendampingan } \\
\text { kelompok }\end{array}$ & $\begin{array}{l}\text { Kegiatan ini dilaksanakan } \\
\text { untuk memfasilitasi anak } \\
\text { sesuai dengan potensi yang } \\
\text { ada di dalam diri anak dan } \\
\text { melakukan pendampingan } \\
\text { sesuai dengan minat dan } \\
\text { bakat anak. }\end{array}$ & $\begin{array}{l}2 \times 60 \\
\text { menit }\end{array}$ \\
\hline $\begin{array}{l}\text { Konseling } \\
\text { Kelompok }\end{array}$ & $\begin{array}{l}\text { Kegiatan ini dilaksanakan } \\
\text { untuk memfasilitasi } \\
\text { kebutuhan anak untuk } \\
\text { menjaga kesehatan mental } \\
\text { dalam memahami dirinya } \\
\text { dan dilatih untuk } \\
\text { keterampilan problem } \\
\text { solving secara mandiri. }\end{array}$ & $\begin{array}{l}2 \times 60 \\
\text { menit }\end{array}$ \\
\hline
\end{tabular}

Berdasarkan tabel diatas kegiatan pengabdian dilaksanakan secara rutin, selama kurang lebih 1 bulan, dimana setiap kegiatan dilaksanakan $1 \mathrm{x}$ dalam seminggu.

\section{Evaluasi Kegiatan}

Evaluasi kegiatan dilakukan dengan melakukan pengamatan yang dilakukan oleh tim pelaksana sesuai dengan lembar pengamatan, untuk mengetahui pengaruh program yang dilaksanakan dalam pengembangan diri anak jalanan dilakukan pengamatan pada setiap kegiatan yang dilaksanakan melalui lembar penilaian sikap dan keterampilan peserta. Selanjutnya untuk mengetahui pengaruh pelaksanaan dari program pendampingan terhadap motivasi anak jalanan diberikan angket motivasi pada awal dan akhir kegiatan. Untuk indikator pada angket motivasi dapat dilihat pada tabel kisi-kisi angket motivasi belajar.

Tabel 2. Kisi-Kisi Angket Motivasi Belajar

\begin{tabular}{|c|c|c|c|c|c|}
\hline Variabel & & Indikator & Item + & Item - & Jumlah \\
\hline \multirow{4}{*}{$\begin{array}{l}\text { Motivasi } \\
\text { Belajar }\end{array}$} & 1) & $\begin{array}{l}\text { Partisipasi dalam } \\
\text { kegiatan }\end{array}$ & 1,3,5, & 2,4 & 5 \\
\hline & 2) & $\begin{array}{l}\text { Ketekunan dalam } \\
\text { mengikuti kegiatan }\end{array}$ & $6,8,12$ & 7,9,11, & 6 \\
\hline & 3) & $\begin{array}{l}\text { Kebiasaan dalam } \\
\text { mengikuti } \\
\text { kegiatan }\end{array}$ & 10,16 & 13 & 3 \\
\hline & 4) & $\begin{array}{l}\text { Semangat dalam } \\
\text { mengikuti kegiatan }\end{array}$ & $\begin{array}{c}14,18 \\
19\end{array}$ & $\begin{array}{c}15,17,2 \\
0\end{array}$ & 6 \\
\hline Jumlah & & & & & 20 \\
\hline
\end{tabular}

\section{Refleksi}

Refleksi dilakukan bersama antara tim dan peserta. Hal ini dilakukan untuk mengetahui seluruh proses pelaksanaan kegiatan.

\section{Hasil dan Pembahasan}

Hasil pelaksanaan kegiatan pengabdian masyarakat yang diikuti oleh 20 peserta diperoleh dua data, yaitu data pengembangan diri melalui lembar kegiatan anak dream actifity, dan data motivasi belajar anak melalui angket motivasi belajar. Adapun hasil pengembangan diri anak dapat dilihat pada tabel ringkasan lembar kegiatan dream activity.

Tabel 3. Ringkasan Lembar Kegiatan Dream

\section{Activity}

\begin{tabular}{lllllll}
\hline No. & Aspek yang & \multicolumn{3}{c}{ Pertemuan Ke- } & $\sum$ & Kategori \\
& dinilai & $\mathbf{1}$ & $\mathbf{2}$ & $\mathbf{3}$ & & \\
\hline 1 & Kognitif & 3 & 3 & 4 & 3 & Baik \\
2 & Keaktifan & 3 & 4 & 4 & 3.6 & $\begin{array}{l}\text { Sangat } \\
\text { Baik }\end{array}$ \\
& & & & & & Baik \\
3 & Disiplin & 3 & 3 & 3 & 3 & Baik \\
4 & Percaya Diri & 3 & 3 & 4 & 3 & Sangat \\
$5 \quad$ & Psikomotorik & 3 & 4 & 4 & 3.6 & Baik \\
& & & & & \\
Persentase & $75 \%$ & $85 \%$ & $95 \%$ & & \\
Rata-rata & & $\mathbf{8 5 \%}$ & & & \\
Kategori & \multicolumn{5}{c}{ Baik }
\end{tabular}

Keterangan : Kurang sekali: (skor 0-1,5), Kurang : (skor 1,6-2,5), Baik: (skor 2,6-3,5), Sangat Baik: (skor 3,6-4,0) Kategori : sangat baik (86-100\%), baik (76-85\%), cukup $(60-75 \%)$, kurang $(55-59 \%)$ dan kurang sekali $(\leq 54 \%)$. (Purwanto, 2012).

Hasil lembar kegiatan dream activity menunjukkkan bahwa pada aspek penilaian kognitif, disiplin, dan percaya diri diperoleh 
skor rata-rata 3 dengan berkategori baik. Sedangkan untuk aspek penilaian keaktifan dan psikomotorik anak diperoleh skor rata-rata 3.6 dengan kategori sangat baik. Kegiatan yang dilakukan pada pertemuan ke 1 merupakan kegiatan Character Building dan Self regulated learning dimana kegiatan ini dilaksanakan untuk memberikan pengetahuan dan wawasan kepada anak jalanan tentang analisa strength (kekuatan) dan potensi dalam diri, serta kegiatan untuk membantu anak dalam manajeman waktu. Kegiatan pada pertemuan ke 2 merupakan kegiatan perencanaan pengembangan diri (Self Planing). Kegiatan ini memfasilitasi anak jalanan dalam merencanakan kegiatan-kegiatan yang harus mereka lakukan guna mencapai citacita yang telah mereka buat sebelumnya pada media dream tree. Adapun cita-cita yang dituliskan oleh anak jalanan dapat dilihat pada gambar dream tree yang dibuat pada kegiatan pertemuan ke 2 .

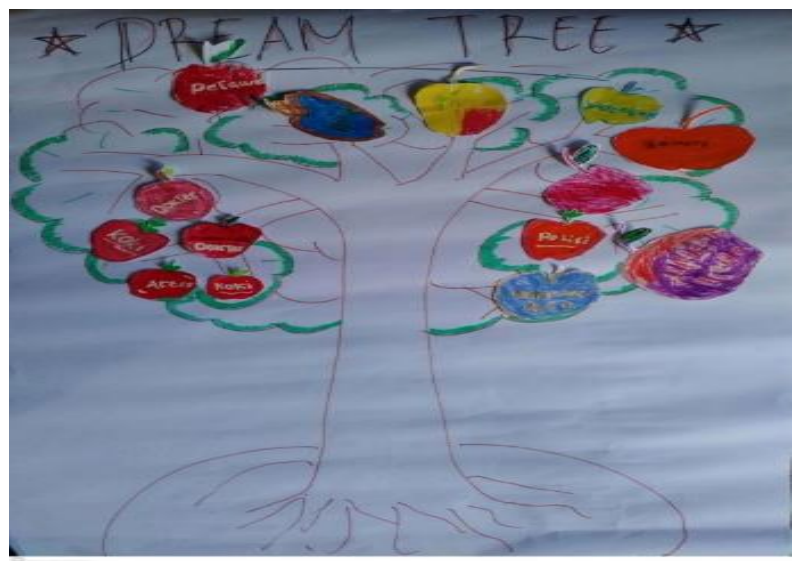

Gambar 4.1 Hasil Kegiatan Anak Jalanan (Dream Tree)

Gambar dream tree yang telah dibuat menunjukkan bahwa terdapat 14 orang anak yang ikut berpartisipasi dalam membuat dream tree dimana masing-masing anak menggambar buah dan menuliskan cita-cita yang ingin dicapai. Terdapat 14 buah apel yang dibuat oleh anak jalanan dimana diperoleh beberapa impian profesi yang dicita-citakan, seperti: dokter, perawat, guru, dokter hewan, pilot, koki, youtuber, gamer, dan milioner. Selanjutkan kegiatan pada pertemuan ke 3 yaitu membentuk kelompok dan konseling kelompok, dimana pada kegiatan ini dilaksanakan untuk memfasilitasi anak sesuai dengan potensi yang ada di dalam diri anak dan melakukan pendampingan guna menjaga kesehatan mental dalam memahami dirinya dan dilatih untuk keterampilan problem solving secara mandiri.

Berdasarkan ringkasan hasil kegiatan pengabdian yang dilakukan, berkaitan dengan pengembangan diri anak jalanan pada pertemuan ke 1 diperoleh $75 \%$, pertemuan ke 2 diperoleh $85 \%$ dan pertemuan ke 3 diperoleh $95 \%$. Dari data tersebut dapat diperoleh rata-rata presentase sebesar $85 \%$ dengan kategori baik. Hal ini menunjukkan bahwa terjadi peningkatan pengembangan diri pada setiap pertemuan yang dilakukan. Dengan demikian kegiatan pengabdian yang dilakukan dapat meningkatkan pengembangan diri anak jalanan.

Hasil data yang kedua berkaitan dengan motivasi anak jalanan dimana hasil data diperoleh dari lembar angket motivasi yang diberikan di awal pertemuan (pretest) dan akhir pertemuan (posttest). Adapun hasil motivasi belajar anak dapat dilihat pada tabel ringkasan hasil motivasi belajar anak jalanan.

\section{Tabel 4. Hasil Angket Motivasi Anak}

\begin{tabular}{|c|c|c|c|}
\hline No. & Indikator & Pretest & Postest \\
\hline 1 & Partisipasi dalam kegiatan & 73 & 85 \\
\hline 2 & $\begin{array}{l}\text { Ketekunan dalam } \\
\text { mengikuti kegiatan }\end{array}$ & 76.6 & 88.3 \\
\hline 3 & $\begin{array}{l}\text { Kebiasaan dalam } \\
\text { mengikuti kegiatan }\end{array}$ & 86.3 & 93.3 \\
\hline 4 & $\begin{array}{l}\text { Semangat dalam } \\
\text { mengikuti kegiatan }\end{array}$ & 75.8 & 91.7 \\
\hline & Total & 311.7 & 358.3 \\
\hline & Rata-rata & 77.9 & 89.6 \\
\hline
\end{tabular}

Sumber : Hasil pengolahan data

Berdasarkan Tabel hasil angket motivasi anak diperoleh nilai pada masing-masing indikator, dimana dari total keseluruhan indikator diperoleh nilai rata-rata pretest sebesar 77.9 dan nilai rata-rata posttest diperoleh 89.6. Hal ini menunjukkan bahwa ada peningkatan motivasi anak sebelum dan sesudah dilakukan kegiatan pengabdian masyarakat. Dengan demikian dapat disimpulkan bahwa kegiatan pengabdian masyarakat yang dilakukan dapat 
meningkatkan pengembangan diri dan motivasi belajar anak jalanan. Hal ini berdasarkan hasil kegiatan pengabdian masyarakat melalui lembar kegiatan dream actifity, dan hasil data motivasi belajar anak melalui angket motivasi belajar.

\section{Kesimpulan}

Berdasarkan hasil kegiatan pengabdian masyarakat yang dilakukan dalam meningkatkan pengembangan diri dan motivasi anak jalanan di Yayasan Anak Bangsa Mandiri Banua Banjarmasin dapat disimpulkan bahwa :

1. Kegiatan ini memberikan tambahan wawasan dan pengetahuan serta pengalaman tentang pengembangan diri anak jalan.

2. Kegiatan ini dapat meningkatkan pengembangan diri dan motivasi anak jalanan.

\section{Saran}

Perlu dilakukan program lebih lanjut secara terus-menerus untuk memberikan informasi tentang pengembangan diri dan motivasi anak jalanan, serta kegiatan-kegiatan positif yang dapat membantu anak jalanan dalam mengasah keterampilan kognitif dan keterampilan kreatifnya. Sehingga anak jalanan dapat terus memperoleh tambahan pengetahuan wawasan dan pengalaman-pengalaman serta keterampilan-keterampilan lain. Agar anak jalanan lebih banyak lagi memperoleh pengalaman dalam belajar untuk mengembangkan potensi di dalam dirinya serta selalu terdorong untuk melakukan halhal yang positif.

\section{Ucapan Terima Kasih}

Terima kasih kepada Universitas Islam Kalimantan Muhammad Arsyad Al-Banjari Banjarmasin yang telah mendukung secara moral maupun material, dan pihak-pihak terkait yang senantiasa selalu memberikan dukungan dalam terlaksananya kegiatan pengabdian kepada masyarakat ini.

\section{Daftar Pustaka}

Efendi, Bahrudi Damanik. 2018. Pengaruh Motivasi Dan Pengembangan Diri Terhadap Prestasi Kerja Dosen. Jurnal Ek \& BI Politeknik Bisnis Indonesia. Volume 1 nomor 12018. https://doi.org/10.37600/ekbi.v1i1.42

Diakses pada tanggal 6 Januari 2021

Handayani, Dita. Nurhayati. Herawati. 2020.

Hubungan antara motivasi siswa dan minat belajar terhadap hasil belajar Bahasa inggris siswa kelas V SD Negeri Cibuluh 6 Kota Bogor. Jurnal Teknologi Pendidikan Volume 9 Nomor 1 Januari 2020. Universitas IBN Khaldun:Bogor. http://ejournal.uika-

bogor.ac.id/index.php/TEK/article/view/27

10 Diakses pada tanggal 13 Desember 2020.

Haryadi, Rudi. Dkk. 2020. Implementasi 21st Century Community Counseling Program Bagi Anak Kurang Beruntung Di Yayasan Anak Bangsa Mandiri Banua. Bubungan Tinggi: Jurnal Pengabdian Masyarakat Volume 2 Nomor 2. Banjarmasin. http://ppjp.ulm.ac.id/journals/index.php/btj/i ndex Diakses tanggal 13 Desember 2020.

Herawan, 2016. Konsep Dan Metode Pengembangan Diri Dalam Buku Kubik Leadership (Analisis Psikologi, Islam, Dan Bimbingan Dan Konseling Islam). IAIN Purwokerto.

http://repository.iainpurwokerto.ac.id/1108/ 1/Cover_Bab\%20I_Bab\%20V_Daftar\%20P ustaka.pdf Diakses pada tanggal 6 Januari 2021

Marni, Erna. 2020. Gambaran Psikososial Anak Jalanan Usia Remaja. Jurnal Keperawatan Abdurrab Volume 3 Nomor 2 Januari 2020. http://jurnal.univrab.ac.id/index.php/kepera watan/article/view/1066 Diakses pada tanggal 13 Desember 2020.

Purwanto, Ngalimun. 2012. Prinsip-prinsip dan Teknik Evaluasi Pengajaran. PT. Remaja Rosdakarya. Bandung

Sakman. 2016. Studi Tentang Anak Jalanan (Tinjauan Implementasi Perda Kota Makasar Nomor 2 Tahun 2008 Tentang Pembinaan Anak Jalanan, Gelandangan, Pengemis, Dan Pengamen Di Kota Makasar. Jurnal Pemikiran, Penelitian IlmuIlmu Sosial, Hukumm dan Pengajarannya. Volume 11 Nomor 2. Universitas Negeri Makasar.

https://ojs.unm.ac.id/supremasi/article/view 12816 Diakses pada tanggal 13 Desember 2020. 
Sugianto. 2013. Perlindungan Hukum Terhadap Anak Jalanan Dalam Prespektif Hukum Positif Dan Hukum Islam (Studi Kasus Pada Yayasan Madinatunajjah Kota Cirebon. Jurnal Syariah dan Hukum, Volume 5 Nomor 2, Desember 2013:Cirebon. https://media.neliti.com/media/publicati ons/23661-ID-perlindungan-hukumterhadap-anak-jalanan-dalamprespektif-hukum-positif-dan-huku.pdf Diakses pada tanggal 13 Desember 2020.

Undang-Undang Republik Indonesia Nomor 23 Tahun 2002 tentang Perlindungan Anak. 